КУРЦЕВ О.Ю.

\title{
УНІТАРИЗМ У СИСТЕМІ ПРИНЦИПІВ КОНСТИТУЦІЙНОГО ЛАДУ
}

Розкрито зміст принципу унітарності держави як засади конституційного ладу. В порівняльному аспекті розглядаються особливості конституційного закріплення принципу унітаризму в Україні та зарубіжних країнах. Вказується, що перед Україною постають ті ж самі проблеми, що й перед розвиненими європейськими державами (деконцентрація та децентралізація повноважень, підвищення фінансової спроможності місцевої влади, оптимальний поділ компетенції між державною владою та місцевим самоврядуванням), а з іншого - проблеми, пов'язані 3 непідконтрольністю частини території (біля 5\%) офіційній владі, необхідністю створення якихось перехідних структур на території «материкової» України, покликаних замінити собою органи квазі-влади, що діють на тимчасово окупованій території. I саме з цих позицій має змінюватися зміст принципу унітаризму як засади конституційного ладу. 3'ясовано, що регіони Іспанії зі спеціальним статутом можуть 3 самого початку здійснювати компетенцію, яка не є винятковою компетенцією держави, крім того, вони користуються більш незалежною процедурою під час розробки статуту, а також організацією вищого рангу самоврядування та адміністрації (президент, законодавча асамблея, урядова рада, верховний суд та інші). Критерій, яким керувалися законодавці, такий: спеціальний статут мають регіони, юридично визнані як такі, що мають найбільше значення і регіональну незалежність. Уся решта регіонів має загальний статут. Тобто спеціальний статут надається так званим історичним регіонам: Каталонії, Країні Басків і Галісії. Наголошено, що за Конституцією України винятково законами України визначається територіальний устрій України, який грунтується на засадах єдності та цілісності державної території, поєднання централізації і децентралізації у здійсненні державної влади, збалансованості соціально-економічного розвитку регіонів, з урахуванням їх історичних, економічних, екологічних, географічних і демографічних особливостей, етнічних і культурних традицій. Крім того, можна відзначити певну зміну акцентів у конституційному регулюванні питань територіально-державного устрою.

Ключові слова: унітаризм, унітарна держава, державна влада, система організаиії державної влади.

The content of the principle of unitarity of the state as a basis of the constitutional order is revealed. In a comparative aspect, the peculiarities of the constitutional consolidation of the principle of unitarism in Ukraine and in foreign countries are considered. It is stated that Ukraine faces the same problems as the developed European states (deconcentration and decentralization of powers, enhancing the financial capacity of local authorities, optimal division of competencies between state authorities and local self-government), and on the other hand, problems related to uncontrolled part of the territory (about $5 \%$ ) to the official power, the need to create some transitional structures in the territory of "mainland" Ukraine, designed to replace the quasi-authorities acting on a temporary basis occupied territory. And it is from these positions that the content of the principle of Unitarianism as the basis of the constitutional order should change. It has been found that regions of Spain with a special statute can, from the outset, exercise a competence that is not the exclusive competence of the state; government, supreme court, etc.). The criterion guided by the legislators is the following: the special status is given to the regions legally recognized as having the greatest importance and regional independence. All other regions have a general status. That is, a special charter is

(C) КУРЦЕВ О.Ю. - здобувач кафедри конституційного права України (Національний юридичний університет імені Ярослава Мудрого) 


\begin{abstract}
granted to the so-called historical regions: Catalonia, the Basque Country and Galicia. It is emphasized that the Constitution of Ukraine exclusively determines the territorial structure of Ukraine, based on the principles of unity and integrity of the state territory, the combination of centralization and decentralization in the exercise of state power, balance of socio-economic development of regions, taking into account their historical, economic, environmental, geographical and demographic characteristics, ethnic and cultural backgrounds. In addition, it is possible to note a certain change of emphasis in the constitutional regulation of issues of territorial-state system.
\end{abstract}

Key words: unitarianism, unitary state, state power, system of organization of state power.

Вступ. Припис стосовно унітарної форми державного устрою України закріплено у розділі I Конституції (ст. 2). Вказаний розділ, а також розділи III і XIII, належать до так званих «засад конституційного ладу», що являють собою ключову категорію сучасного конституційного права.

Прикметно, що вказані розділи Конституції можуть змінюватися винятково у процедурі всеукраїнського референдуму. Як наслідок, вони $є$ незрівнянно більш стабільними, аніж інші розділи Основного Закону. Мабуть, саме тому за 28-річну історію незалежної України до них ніколи не вносилися зміни. Проте після трагічних подій 2014 року в нашій країні питання територіального устрою набуло особливої актуальності. Насамперед це пов'язане з анексією Російською Федерацією Автономної Республіки Крим (далі - АРК), а також сепаратистськими тенденціями на сході країни, задля придушення яких необхідно діяти не лише військовими, а й економічними та правовими засобами.

Постановка завдання. Метою статті є дослідження явища унітаризму у системі принципів конституційного ладу.

Результати дослідження. Однією зі спроб певного корегування конституційних положень щодо унітарної форми нашої держави поза змінами статті 2 була так звана «децентралізація», покликана посилити економічну i, певною мірою, політичну спроможність адміністративно-територіальних одиниць. Але, попри підтримку Конституційного Суду, остаточне рішення так і не було ухвалено парламентом. Разом з тим у своєму Висновку від 30.07.2015 p. № 2-в/2015 орган конституційної юрисдикції зазначив, що жодне із запропонованих Президентом положень (зокрема, щодо запровадження фігури префекта замість голови місцевої державної адміністрації, конституювання регіону як самостійної адміністративно-територіальної одиниці та інше) не передбачає скасування чи обмеження прав і свобод людини і громадянина або посягань на конституційний лад держави.

Як би там не було, питання територіальної організації публічної влади традиційно залишається обов'язковим елементом конституційного регулювання на всіх етапах його розвитку. Для сучасного періоду, як зазначає О.О. Троїцька, характерне зростання інтересу до організації територіально-державного устрою в контексті формування наднаціонального рівня прийняття політико-правових рішень, розширення регіонального самоврядування та добровільної передачі державою публічно-владних повноважень на наднаціональний і регіональний рівень [1, с. 27]. Про це свідчить здійснення серйозних конституційних реформ у кінці XX - на початку XXI століть у низці держав (Аргентина - 1994 р., Великобританія - 1998 р., Швейцарія - 1999 р., Італія - 2001 р., Франція - 2003 р., ФРН - 2006 р.). Слід зазначити, що в багатьох випадках серйозні зміни територіальної організації країни здійснювалися на законодавчому рівні без внесення змін до тексту конституції. Так, в Італії в 1999 р. в рамках адміністративної реформи була здійснена деволюція адміністративних повноважень територіальним колективам [2, с. 21].

Як нову тенденцію можна відзначити закріплення на конституційному рівні принципів організації державно-територіального устрою. Для унітарних держав зазвичай характерні принципи децентралізації (ст. 1 Конституції Франції, ст. 224 Конституції Гватемали, ст. 15 Конституції Польщі, ст. 144 Конституції Сменської Республіки) та автономії (ст. 6 Конституції Португалії, ст. 119 Конституції Румунії, ст. 1 Конституції Колумбії, ст. 200 Конституції Болівії). Виділення принципів субсидіарності (ст. 5а Конституції Швейцарії, ст. 23 Основного закону ФРН, ст. 6 Конституції Португалії, ст. 118 Конституції Італії, ст. 72 Конституції Франції, ч. 2 ст. 228 Конституції Колумбії), пропорційності (ст. 118 Конституції Італії) і кооперації (ст. 41 Конституції ПАР) більшою мірою властиво федеративним і регіональним державам.

За Конституцією України винятково законами України визначається територіальний устрій України (пункт 13 частини першої статті 92), який грунтується на засадах єдності та ці- 
лісності державної території, поєднання централізації і децентралізації у здійсненні державної влади, збалансованості соціально-економічного розвитку регіонів, з урахуванням їх історичних, економічних, екологічних, географічних і демографічних особливостей, етнічних і культурних традицій (стаття 132).

Крім того, можна відзначити певну зміну акцентів у конституційному регулюванні питань територіально-державного устрою. Замість структурного підходу поступово приходить функціональний, тобто все більше уваги приділяється підвищенню ефективності рішень, що приймаються органами публічної влади різного рівня, і оперативності їх здійснення, оптимізації територіального устрою.

Однією з найхарактерніших ознак конституційного закріплення унітаризму насамперед $\epsilon$ те, що країни, які вважаються унітарними, не закріплюють безпосередньо в Основному Законі відповідне положення, як, наприклад, це зроблено у Конституції України. Так, у Конституції Данії взагалі не вказано ані форму територіального устрою, ані засади функціонування місцевого самоврядування. Вважається, що це - прерогатива окремих законів, якими в цій країні є Закон про регіони і встановлення амт-комун 2012 р., а також Закон про комунальне управління того ж року [3, с. 12]. У Чехії у ст. 11 Конституції безпосередньо вказано, що територія Чеської Республіки являє собою неподільне ціле, а ії державні кордони можуть змінюватися тільки конституційним законом, проте чіткого формулювання стосовно форми державного устрою теж немає [4]. Конституція Франції містить лише розділ XII «Про адміністративно-територіальні утворення», хоча у першій статті конституції вказано, що «Франція $є$ неподільною республікою... Ї̈̈ устрій $є$ децентралізованим» [5]. Навіть у Конституції Сербії, що пережила громадянську війну спочатку за «югославську спадщину» (1991-1995рр.), а згодом - з автономним краєм Косово (19992000 рр.), відсутня чітка вказівка на форму державного устрою; підкреслюється лише, що Косово та Метохія є нероздільними частинами Сербії (ст. 182) [6]. Нарешті, усім відомо про потужні процеси деволюції (фактично тієї ж децентралізації), що йдуть сьогодні у формально унітарній Великій Британії [7].

У цьому контексті закріплення в Конституції України принципу унітаризму серед принципів конституційного ладу, які відрізняються підвищеною стабільністю завдяки ускладненій процедурі внесення змін до них, виглядає дещо незвичним. Як ми бачили, частіше у конституціях вказується або на єдину та неподільну державну територію як таку, або на децентралізований характер влади у тій чи іншій унітарній державі. Разом з тим слід враховувати, що в історико-правовому аспекті кожна країна проходила свій унікальний шлях під час вибору та подальшого закріплення на конституційному рівні форми державного устрою. Як зазначає О.Г. Кушніренко, «унітаризм замінив партикуляризм і феодальну роздробленість, відіграв свою прогресивну роль. Він не залежав від національно-етнічної чи расової структури населення, а був затребуваний єдиним режимом, відносною простотою в здійсненні державної влади» [8, с. 18].

Так, територіальна цілісність французької держави вперше була закріплена в Конституції 1791 р. Стаття 1 встановлювала, що королівство єдине і нероздільне і складається з 83 департаментів. Ця норма поклала край майже тисячолітній традиції феодальної роздробленості. Що ж стосується Конституції 1791 р., то поява в ній норми про територіальну єдність мала своїм наслідком усунення формальних відмінностей між революційно і охоронно налаштованими регіонами Франції. Вказане положення зводило на конституційний рівень відомі декрети Національних зборів, ухвалені 4 серпня 1789 р., і скасовувало багато в чому віджилі норми феодального права. Але більш важливим уявляється той факт, що в ту пам'ятну ніч 4 серпня революційні депутати відмовили французьким провінціям у праві на збереження своєї історичної самобутності. Всі вони повинні були відтепер з'єднатися в загальному нормативному просторі для боротьби за ідеали Просвітництва. Таким чином, припис ст. 1 Конституції 1791 р. перетворив Францію на єдину націю, що заперечувала містечкові особливості окремих етнічних груп [9, с. 94]. В результаті «Батьківщина прав людини» дуже скоро перетворилася на державу з гранично централізованою владою.

Надмірна централізація територіального устрою довгий час відрізняла Францію. Ця спадщина революції 1789 року та Першої Республіки відчувалася протягом усього ХІХ ст. і більшої частини XX ст. Нам видається, що головну причину слід шукати в філософському виправданні революційних подій 1789 р. Адже в дійсності радикальні перетворення кінця XVIII ст. аж ніяк не віталися більшістю населення. Однак, як воно часто буває, основна маса жителів поставилася пасивно до краху монархії, і лише в деяких регіонах наміри революціонерів зустріли шалений опір. Приклад вандейського протистояння досить красномовний. У будь-якому разі у Франції 
не вийшло тріумфальної ходи республіканських ідей. Отже, поборники просвітницької філософії вирішили нав'язати свою волю всьому народові тільки за допомогою насильства. А воно за визначенням вимагає концентрації влади. Відомих успіхів у цій справі досягли якобінці, проте навіть їх падіння в 1794 р. не могло переламати тенденцію, що намітилася. Пояснення тут може бути лише одне: всі наступні режими тією чи іншою мірою були онтологічними продовжувачами того руссоїстського тоталітаризму, найвищим втіленням якого виявилася «Гора». Нові цінності епохи Модерну (головна 3 яких і є республіка) слід було вкорінювати і підтримувати постійно. А зробити це можна було тільки за допомогою грубої сили.

Однак кінець XX в. приніс з собою протилежну тенденцію в галузі місцевого самоврядування сучасної Франції. Замість об'єднавчої і зрівнюваючої політики ми спостерігаємо спочатку боязливі, але потім все більш наполегливі спроби зберегти деякі незначні, але від цього ще більш дорогоцінні, залишки локальної самобутності. Більшою мірою це, звичайно, стосується заморських володінь П'ятої Республіки. Вони належать іншій культурі, незважаючи на багатовікову французьку присутність. Але й місцеві території в метрополії мають все ж низку особливостей, які не змогло витравити двухсотрічне панування ідеології Модерну. При цьому тверезий погляд на речі змушує нас визнати, що відмова від централізму в територіальному устрої була продиктована причинами скоріше економічними і фінансовими, ніж такою, що раптом прокинулась, турботою паризьких бюрократів про «вікопомний» дух глибинної Франції. Ефективність управління та оптимізація ресурсів - ось мета реформ місцевого самоврядування П'ятої Республіки [10, с. 75].

31982 р. послідовне розширення можливостей земств протікає в двох взаємодоповнюючих один одного напрямах. Ці останні отримали найменування децентралізації і деконцентраціі. Варто зазначити, що тривалість і глибина вироблених змін у французькому державному устрої до такої міри відчутні, що дозволяють казати про тенденцію, що цілком склалася. Остання відрізняє Францію від іiі сусідів і в будь-якому разі додає П'ятій Республіці певну своєрідність. Ми сміємо стверджувати, що територіальний устрій сучасної Франції є елементом іїі конституційної самобутності. Закріплення в 2003 р. децентралізації як однієї із засад конституційного ладу не може не переконати нас у правомірності висловленої позиції.

В Іспанії на цей час існують 17 регіональних спільнот. Місцевий рівень адміністрації представлений 50 провінціями і 8000 муніципалітетами. Автономні інститути впроваджуються за наступною схемою: президент, законодавча асамблея, урядова рада і судова організація з різними ієрархіями. Назви приймаються відповідно до історичних традицій: Женералітет в Каталонії, Генеральна рада в Країні Басків, Хунта в Галісії, Загальні збори представників (la Diputacion General) в Арагоні та інші [11, с. 224].

Під час розгляду територіального устрою Королівства Іспанії слід також задатися питанням про конституційний лад іспанської держави. Чи $є$ Іспанія згідно з ним унітарною або федеративною державою?

Цікаво, що природа іспанської держави не збігається з традиційною схемою унітарної держави, але також вона не співпадає і з традиційною схемою федеративної держави. Діалектики центризму-федералізму консервативного сектора захищають перше, а діалектики соціалістів, комуністів і національних меншин - друге. Більшість іспанських юристів вважає, що Іспанія знаходиться на третьому шляху, який є найбільш близьким і до тієї, і до іншої класичної концепції держави з погляду територіальної організації. Нещодавно Іспанію стали відносити до категорії регіоналістських держав, що надають складовим частинам країни значну ступінь автономії, що відрізняє ії від унітарних централізованих держав, але не досягає ступеня самостійності суб'єктів федерації [12].

У юридичній літературі виділяють такі характерні ознаки регіоналістської держави: деволюційний спосіб утворення; розмежування компетенції між центром і регіонами з закріпленням залишкової компетенції за центральною владою; здійснення контролю за діяльністю регіонів органами конституційного рівня (конституційний суд, уряд, рахункова палата); наділення регіонів правом прийняття законів без надання їм установчих повноважень; різний ступінь самостійності регіонів; відсутність у регіонів можливості брати участь у здійсненні державних повноважень (перегляд Конституції країни; представництво у верхній палаті парламенту, повноваження у сфері судоустрою) [2, с. 23].

Справедливості заради відзначимо, що останнім часом багато говорять про вплив Конституції Італії 1947 р. на концепцію територіального устрою сьогоднішньої Іспанії. Є думка, що регіональна організація держави була запозичена з італійської моделі, оскільки саме в останній наявна відмінність між двома категоріями регіонів [12, с. 13]. Зокрема, в регіональних автоном- 
них утвореннях існує два типи статутів: загальний і спеціальний. Іншими словами, слід розрізняти території, яким було надано тимчасовий автономний режим, i ті, які мали такий режим 3 моменту набуття чинності Конституції Іспанії 1978 р. Для них встановлені різні шляхи набуття автономного устрою. Регіони із загальним статутом характеризуються тим, що межі їх компетенції обмежуються повноваженнями, встановленими самою Конституцією. Тільки через п'ять років після створення вони зможуть розширити свою компетенцію, але ні в якому разі вони не можуть набути виняткову компетенцію держави.

Регіони зі спеціальним статутом можуть з самого початку здійснювати компетенцію, яка не $\epsilon$ винятковою компетенцією держави, крім того, вони користуються більш незалежною процедурою під час розробки статуту, а також організацією вищого рангу самоврядування та адміністрації (президент, законодавча асамблея, урядова рада, верховний суд та інші). Критерій, яким керувалися законодавці, такий: спеціальний статут мають регіони, юридично визнані як такі, що мають найбільше значення і регіональну незалежність. Уся решта регіонів має загальний статут. Тобто спеціальний статут надається так званим історичним регіонам: Каталонії, Країні Басків і Галісії [11, с. 224]. Таким чином, межі регіональних автономних утворень співпадають 3 межами історичних іспанських регіонів; своєю чергою Мадрид знаходиться на особливому положенні.

Розділ 8 Конституції Іспанії «Про територіальний устрій держави» присвячений визначенню регіонального устрою держави. У ньому містяться такі підрозділи, як «Загальні засади» (ст. ст. 137-139 Конституції Іспанії). В останній визначено, що держава за територіальною ознакою організовується за муніципалітетами, провінціями і регіональними автономними утвореннями. Всі вони користуються автономією під час ведення своїх справ [13].

Іспанія вважається унітарною державою. Основною адміністративно-територіальною одиницею в Іспанії є регіональне автономне утворення (comunidad autônoma; іноді в вітчизняних текстах вживаються такі терміни, як автономна область, регіональна автономна спільнота та інші). Всі регіони Іспанії мають автономію, проте Країна Басків і Каталонія мають ширші повноваження.

Створення регіональних автономних утворень передбачено Конституцією 1978 р. Стаття 152.1 Конституції встановлює їх інституційну основу - законодавчу асамблею, що обирається загальним голосуванням, раду уряду з виконавчими функціями та голову регіонального автономного утворення, який обирається законодавчою асамблеєю.

Своєю чергою Італія як єдина держава остаточно сформувалася в 1870 р. Чинна Конституція 1947 р. у частині територіального поділу держави кілька разів була змінена. Вона визначає Італію як єдину і неподільну державу [14]. У той же час держава не тільки визнає місцеві автономії, а й гарантує найширшу адміністративну децентралізацію. Стаття 114 Конституції Італії встановлює розподіл Республіки на області, провінції, великі міста та комуни. Вона передбачає автономію областей, провінцій, великих міст і комун, яка повинна здійснюватися відповідно до принципів, що передбачені Конституцією Італії.

Таким чином, в конституційному сенсі Італія - це децентралізована унітарна держава. Особливість її адміністративно-територіального устрою полягає в тому, що Італія - єдина (унітарна) держава, розділена на області; кожна область $є$ автономією, що являє собою рідкісне явище в світовій практиці. За влучним висловом Г.В. Шашкової, Італія уособлює риси унітарної держави (єдність країни) та федерації (велика автономія областей) [11, с. 243].

Області користуються фінансовою самостійністю, яку передбачалося серйозно розширити в зв'язку з прийняттям конституційного закону про федеративний устрій Італії. Однак і за нині чинним законодавством в розпорядженні областей знаходяться місцеві податки і частка від державних податків, що визначається залежно від конкретних потреб області. У той же час область не може встановлювати власні мита на ввезення, вивезення або транзит між областями, перешкоджати вільному пересуванню осіб та майна, обмежувати право громадян займатися своєю професією, служити або працювати в будь-якій частині національної території [11, с. 243].

Кожна область має офіційний герб і прапор, а також свій статут, в якому визначені конкретні сфери обласного регулювання, компетенція і внутрішня організація галузі, включаючи право законодавчої ініціативи і референдуму, а також право прийняття обласних законодавчих норм.

У Конституції Італії визначено перелік питань, за якими область має право приймати власні закони за умови, що такі закони не будуть суперечити національним інтересам і інтересам інших областей. До предмету відання області входять: організація відомств і адміністративних установ, підпорядкованих області, визначення територіального устрою області, включаючи території комун, і низка інших питань. 
Розглядаючи процеси перетворення, що тривають у територіальній організації влади в Італії, не можна залишити поза увагою спроби федералізації цієї держави, що в останнє мали місце у 2000-х роках. Двічі - в 2001 і 2006 роках - у підготовлених конституційних законах передбачались серйозні зміни територіальної організації публічної влади, схвалені парламентом країни і винесені на загальнонаціональний референдум. Однак доля цих законів склалася по-різному.

Перший проект отримав підтримку виборців, і Конституційний закон № 3 від 18 жовтня 2001 року вніс зміни в главу V «Області, провінції та комуни» Конституції. У рамках реформи змінювався порядок розмежування компетенції між органами державної влади країни і областями; скасовувалася посада урядового комісара в області; регіонам надавалися установчі повноваження, право ухвалення виборчих законів; перевірка обласних законів на відповідність Конституції здійснювалася в порядку наступного, а не попереднього контролю; уряд мав право заміщати органи територіальних колективів у разі невиконання ними норм міжнародних договорів і актів Європейського Союзу, а також у разі серйозної загрози національній безпеці. Крім того, особливі форми і умови автономії могли надаватися областям, не перерахованим у Конституції як області зі спеціальним статусом, на підставі закону Республіки, прийнятого за ініціативою зацікавленої області після заслуховування думки муніципалітетів з урахуванням принципу фінансової автономії територіальних колективів. У число адміністративно-територіальних одиниць включені також метрополітанські міста.

Другий проект - «Про внесення змін до Частини II Конституції» - був схвалений палатами парламенту (Палатою депутатів - 15 жовтня 2004 року, Сенатом - 23 березня 2005 року), але не отримав підтримки населення на референдумі 25 червня 2006 року. Цей проект передбачав, зокрема, уточнення предметів відання з питань виняткової компетенції держави та конкуруючої компетенції держави та областей, а також закріплення виняткової компетенції областей; створення Федеративного Сенату з 252 членів, що обираються в кожній області в процесі виборів відповідних обласних рад; визначення форм контактів між сенаторами і територіальними колективами; введення процедури політичного контролю центральної влади за обласними законами; наділення комун, провінцій і метрополітанських міст правом звернення до Конституційного суду у тих випадках, коли, на їхню думку, закон або акт, який має силу закону держави або області, утискає їх конституційно гарантовані повноваження [2. с. 24].

Оскільки в Італії конституційна реформа 2006 року не отримала підтримки населення, італійські законодавці пішли шляхом розробки законодавства, необхідного для втілення в життя конституційної реформи 2001 року. Зокрема, у 2009 році було схвалено Закон про делегування уряду повноважень у сфері фінансового федералізму на виконання положень статті 119 Конституції.

Специфіка української моделі закріплення унітаризму на конституційному рівні, окрім вказаних на початку статті моментів, полягає також у тому, що досі остаточно не з' ясована природа конституційного ладу як такого. Наприклад, у своєму Рішенні від 11 липня 1997 року № 3-зп Конституційний Суд України підкреслив, що засади конституційного ладу містяться лише у розділах I, III, XIII Конституції (абзац перший пункту 4 мотивувальної частини). Причому академік Ю.М. Тодика стверджував, що серед вказаних розділів особливого значення набувають положення саме розділу I, оскільки вони є так званими принципами засад конституційного ладу, тобто «конституцією в конституції» [15, с. 35].

Російський дослідник О.Г. Рум'янцев виводив засади конституційного ладу не стільки з їх нормативного закріплення, скільки 3 моральних природно-правових засад. Зокрема, він зазначав, що «взаємозв'язок між базовими цінностями суспільства і правовими принципами повинен чітко простежуватися в Конституції. Включені в текст цінності виступають як соціально-моральні регулятори. «Прив'язка» правових норм до основоположних орієнтирів дозволить забезпечити стійкість ладу і не допустити його знецінення з плином часу. Фундаментальні цінності $\epsilon$ відображенням надзавдання, яке народ втілює в конституційному ладі. I навпаки: останній відображає прагнення до щастя, добра, справедливості, свободи, рівності, солідарності, рівноваги і порядку, що лежить в глибинах людської психології» [16, с. 37].

В Україні, як відомо, лише I, III та XIII розділи Основного Закону передбачають безпосереднє народне голосування у разі внесення змін до них. У зв'язку з цим слід звернути увагу на те, що у низці країн (зокрема, у Нідерландах та Ісландії) обов'язковою стадією внесення змін до Конституції є розпуск парламенту. Це пов'язано з тим, що за новими правилами бажано грати вже новим політичним гравцям. Тому низка дослідників, серед яких Ю.Г. Барабаш та Г.В. Берченко, вважають, що аналогічну процедуру слід запровадити й в Україні, особливо у разі розробки оновленого конституційного тексту. Як підкреслює Г.В. Берченко, така процедура проведення 
конституційної реформи є однією з найоптимальніших та має бути розглянута як перспективна для впровадження під час реформування чинного Основного Закону [17, с. 68].

На цей час в Україні унітаризм як принцип конституційного ладу двічі захищався Конституційним Судом. I якщо другий раз - у 2014 р. - відповідне Рішення було ухвалене з певним запізненням та фактично не було виконане, то у 2003 р. воно зіграло свою стабілізуючу роль. Йдеться про Рішення від 16 січня 2003 р. № 1-рп/2003 у справі про Конституцію АРК. У ньому Суд, зокрема, зазначив: «Стаття 2 Конституції України встановлює, що суверенітет України поширюється на всю ії територію. Це $є$ конституційним закріпленням територіального верховенства України... Отже, положення пункту 2 статті 7 Конституції АРК, за яким «територію АРК може бути змінено з урахуванням рішення республіканського (місцевого) референдуму та рішення Верховної Ради АРК», можна реалізувати лише відповідно до Конституції та законів України за рішенням Верховної Ради України». Аналіз названого Рішення ще раз доводить некоректність будь-яких спроб обгрунтувати анексію Криму посиланнями на автономний статус території, як це роблять деякі російські вчені [18, с. 73-81], адже ані Конституція України, ані національне законодавство не закріплювало за автономією права виходу зі складу України, а будь-які рішення, що приймаються на території АРК чи то республіканським референдумом, чи то представницьким органом, повинні відповідати Конституції та законам України. До цього їх зобов'язує імператив унітаризму.

Висновки. Таким чином, перед Україною постають ті ж самі проблеми, що й перед розвиненими європейськими державами (деконцентрація та децентралізація повноважень, підвищення фінансової спроможності місцевої влади, оптимальний поділ компетенції між державною владою та місцевим самоврядуванням), а з іншого - проблеми, пов'язані з непідконтрольністю частини території (біля 5\%) офіційній владі, необхідністю створення якихось перехідних структур на території «материкової» України, покликаних замінити собою органи квазі-влади, що діють на тимчасово окупованій території. I саме з цих позицій має змінюватися зміст принципу унітаризму як засади конституційного ладу.

\section{Список використаних джерел:}

1. Троицкая А. Федерация и региональное государство: где проходит граница? Сравнительное конституционное обозрение. 2009. № 6. С. 27.

2. Васильева Т. Современные формы государственно-территориального устройства: конституционная регламентация в зарубежных странах. Сравнительное конституционное обозрение. 2010. № 2. С. 21 .

3. Ракитская И.А. Конституционно-правовые основы территориального устройства Дании. Конституционно-правовые основы территориального устройства в зарубежных странах / Под ред. К.В. Карпенко. Москва : МГИМО-Университет, 2018. С. 12.

4. Конституция Чехии (Чешской республики). URL: https://legalns.com/download/books/ cons/czech republic.pdf.

5. Конституция Франции. URL: https://worldconstitutions.ru/?p=138\&attempt=1.

6. Конституция Сербии. URL: https://worldconstitutions.ru/?p=369.

7. Лейланд П. Деволюция в Великобритании: новые аспекты динамики конституционного процесса. Сравнительное конституционное обозрение. 2012. № 1. С. 25-46.

8. Кушніренко О. Унітаризм як базова цінність конституційного ладу України. Віче. 2012. № 2. C. 18.

9. Карпенко К.В. Конституционно-правовые основы территориального устройства Франции. Конституционно-правовые основы территориального устройства в зарубежнных странах. С. 94.

10. Доморацкая И.Э., Маклаков В.В. Региональная политика во Франции (правовые аспекты). Известия вузов. Правоведение. 1979. № 6. С. 75.

11. Шашкова А.В. Конституционно-правовые основы территориального устройства Испании.

Конституиионно-правовые основы территориального устройства в зарубежных странах. С. 224.

12. Испания. Конституция и законодательные акты. Москва : Прогресс, 1982. С. 13.

13. Испанская конституция. URL: http://vivovoco.astronet.ru/VV/LAW/SPAIN.HTM.

14. Конституция Италии. URL: https://worldconstitutions.ru/?p=148.

15. Тодыка Ю.Н. Основы конституционного строя. Харків : Факт, 1999. С. 35.

16. Румянцев О.Г. Основі конституционного строя России. Москва : Юрист, 1994. С. 37.

17. Берченко Г.В. Концепція установчої влади та іï розвиток в Україні. Вісник ХНУ ім. В.Н. Каразіна. 2014. Вип. 18. Сер. Право. С. 68.

18. Толстых В. Право на самоопределение как юридическое основание воссоединения Крыма с Россией. Сравнительное конституичинное обозрение. 2014. № 5. С. 73-81. 